\title{
Unsettling planning theory
}

Planning Theory 2018, Vol. 17(3) 418-438 (C) The Author(s) 2018

Reprints and permissions: sagepub.co.uk/journalsPermissions.nav DOI: $10.1|77 /| 4730952 \mid 8763842$ journals.sagepub.com/home/plt

Janice Barry

@SAGE

University of Manitoba, Canada

\section{Megan Horst}

Portland State University, USA

\section{Andy Inch}

Instituto de Ciências Sociais, Universidade de Lisboa, Portugal; The University of Sheffield, UK

\section{Crystal Legacy}

The University of Melbourne, Australia

\section{Susmita Rishi}

University of Washington, USA

\section{Juan J Rivero}

Barnard College, USA

\section{Anne Taufen}

University of Washington, Tacoma, USA

\section{Juliana M Zanotto}

University of California, Irvine, USA

\section{Andrew Zitcer}

Drexel University, USA

\section{Corresponding author:}

Andy Inch, Department of Urban Studies and Planning, The University of Sheffield, Sheffield SIO 2TN, UK.

Email: andy.inch@ics.ulisboa.pt 


\begin{abstract}
Recent political developments in many parts of the world seem likely to exacerbate rather than ameliorate the planetary-scale challenges of social polarization, inequality and environmental change societies face. In this unconventional multi-authored essay, we therefore seek to explore some of the ways in which planning theory might respond to the deeply unsettling times we live in. Taking the multiple, suggestive possibilities of the theme of unsettlement as a starting point, we aim to create space for reflection and debate about the state of the discipline and practice of planning theory, questioning what it means to produce knowledge capable of acting on the world today. Drawing on exchanges at a workshop attended by a group of emerging scholars in Portland, Oregon in late 2016, the essay begins with an introduction section exploring the contemporary resonances of 'unsettling' in, of and for planning theory. This is followed by four, individually authored responses which each connect the idea of unsettlement to key challenges and possible future directions. We end by calling for a reflective practice of theorizing that accepts unsettlement but seeks to act knowingly and compassionately on the uneven terrain that it creates.
\end{abstract}

\title{
Keywords
}

unsettlement; planning theory; knowledge production; reflective practice

\section{Introduction}

We live in unsettling times. While this lament may be endemic to the human condition, social polarizations and environmental degradations of the early 21 st-century raise anew questions about our ability to protect and plan for any kind of common future. From the United Kingdom's decision to leave the European Union to the election of Donald Trump as President of the United States, various fears, anxieties, uncertainties, and resentments are finding political expression. The fragile system of global geopolitical and economic order that emerged in the wake of the Cold War seems to be gradually unraveling as the social and spatial inequalities they produced are sparking agitation and opposition, but without the outlines of any clear alternative coming into view (Streeck, 2016). At the local and regional scales, political and social resistance extends across North America and the United Kingdom, but also France, Sweden, Greece, and Turkey as outlined in the recent book by Mustafa Dikeç (2017) Urban Rage: The Revolt of the Excluded. Protests and rage are also found outside the urban environment, as when long-standing environmental concerns over the pace of natural resource extraction find commonalities with Indigenous peoples' ongoing struggles for recognition: the 2016 Standing Rock protests in South Dakota being one of many examples. This troubling conjuncture raises questions about how to intervene and steer societal trajectories in the 21 st century, questions that are central to urban planning.

As Friedmann (2008) reminds us, planning theorists have a particular role to play in interpreting and responding to the times we find ourselves living within:

Theorists are forever watching the world as it goes through its transformations. For some this is an exciting project, but planners are not journalists who can dispassionately observe the passing scene. They have to ask themselves, given the reality of what is happening, can planning powers intervene to shift the balance of forces towards goals of social justice and 
inclusion in the ongoing process of urban and regional restructuring, and with what tools at hand? (p. 250)

If planning theory has long concerned itself with the translation of knowledge to action (Campbell, 2012; Friedmann, 1987), we argue here that any response to unsettling times must reexamine where and how planning knowledge is produced, shared, and valued and how that affects the forms of action such knowledge makes possible. To the extent that theory sets the terms of debate and intervention for planning action, we note how difficult it has been for our field to establish ways of knowing that either complicate the drive for action or reshape outcomes for people or the planet. For instance, communicative reason promises to bring people together in new and creative ways. But too often they are invited to take a seat at the table only to find the real decisions have already been made elsewhere. Agonistic conflict provides an alternative means of engaging, but the inequality of arms between adversaries is often marked.

In searching for ways forward, it is important to question how such theories shape the possibilities we see in the world such that other knowledges, positions, and practices may be rendered invisible. This has been a persistent concern within planning theory (Porter, 2010; Watson, 2003), particularly for theorists working at the margins of the White, bi-continental centers of planning thought who have drawn attention to alternative translations of knowledge to action (see contributions to Sandercock, 1998a). One example of this effort can be found in Indigenous planning scholars' challenge to the mainstream planning academy. Such work calls attention to the deep sense of personal, political, and intellectual unsettlement that comes from a "normative framework that privileges settler [non-Indigenous] understandings of place and space" (Patrick, 2017: 747). Matunga (2017) takes this line of thinking a step further, suggesting that if "[planning] theories do not fit, and if they cannot or worse still will not, comprehend indigenous experience - the only option left is to ditch them" (p. 641). In this unusual, multi-authored essay, we draw inspiration from these Indigenous scholars' comments on the need to unsettle the planning academy by questioning who is producing planning theory and for what purposes. We wish to argue that the challenges associated with the production of planning knowledges needs to be repositioned at the center of theoretical inquiry for three key reasons:

- First of all, even when planning action has been taken beyond the bounds of what technocratic, rational analysis (the target of early planning theory) would recommend, empirical conditions demonstrate that socio-spatial planning has not been successful at providing for the interests of many people and environments around the globe. Thus, it seems essential to ask ourselves: are we posing the right questions that can help advance understanding of the knowledge(s)-action(s) relationship? What knowledges then are shaping these trajectories-whose are they, where and how are they produced and sustained, and how can planning theory help to expose and reconstitute these processes?

- Second, because knowledge does shape action, if imperfectly and inefficiently, its sources and purveyors and actors, and the networks and practices in which they are embedded, become crucial sites of inquiry. Knowledge production is a social practice, organized by institutional patterns and relational power that reach far 
beyond the intentions of individual planners or theorists. Seeking to pull apart the moments and settings where such biases are reproduced, with an eye toward reconstituting the assemblage in ways that elevate different actors, perspectives, and ways of knowing, is a crucial task.

- Finally, in unsettling times, it is necessary to ask unsettling questions about the role and purpose of planning theory.

\section{Background and context}

In this essay, we take up some of these questions of knowledge production by questioning the role of unsettling in, of, and for planning theory. Our intention is not to offer a comprehensive treatment of the issue but rather to chart diverse points of entry through which we might respond to contemporary challenges. We start from the position that the progress of our discipline depends on our collective ability to generate new empirically grounded insights to advance theory that addresses the multiple inequalities, injustices, and environmental degradations that characterize urban regions today. Yet the task of planning theory cannot only be to explain such processes. It must also respond to planning's imperative to take action; to find ways of ameliorating inequities and reshaping the forces that reproduce them. Scanning the horizon, we must look to identify key challenges and consider how the next generation of planning theory can become a useful tool (or weapon) for thinking, knowing, and acting on them. But we may also need to look inward and ask whether there are important debates that have shaped our field that are in need of unsettling if planning theory is to retain both analytical and activist relevance.

In November 2016, Janice, Andy, Crystal, and Anne invited 24 early-career planning scholars to meet in advance of the Association of Collegiate Schools of Planning conference in Portland to discuss the contemporary issues facing planning theory. The "Unsettling Planning Theory" workshop was a very deliberate attempt to create new spaces for collegial - and challenging - discussion among emerging voices in planning theory. The list of invitees was drawn from recent presenters in the Planning Theory Track at ACSP and, to a lesser extent, the Association of European Schools of Planning and World Planning Schools Congress. ${ }^{1}$

The theme of "Unsettling" was chosen for its multiple suggestive possibilities and capacity to act as a productive point of departure. Some of these possibilities were explored in an introductory "provocation" written by the four workshop conveners. The provocation included reflections on communicative, agonistic, just city, sustainability, new materialism, and radical/insurgent approaches to planning theory; their potential and limitations in addressing the systemic effects of sexism, racism, colonialism, environmental degradation, neoliberalism, and anthropocentrism. Three dimensions of unsettlement formed the basis of the subsequent workshop session-political; cognitive, emotional, and affective; and material, physical, and spatial - with participants drawing attention to the complex interrelations between each of these categories, and the wide range of questions raised by the multiple meanings of unsettling. The discussion continued at a well-attended roundtable session during the ACSP conference that generated a wide range of responses from both early-career and more established scholars. These 
ranged from enthusiastic support for the idea of consciously seeking new directions for planning theory to others who seemed to feel that the key fights have already been fought (and maybe even won). Collectively they laid down a series of important challenges, not least to define what might need unsettling and why.

This essay is intended as a means of responding to these challenges and extending the debates begun in Portland. We start with a summary framing of unsettlement and its rich and potentially challenging resonances for planning theory. The responses that follow are written by workshop participants who connect the idea of unsettlement to key challenges they face in planning theory today. Collectively we ask, is planning theory up to the task of producing knowledge for these unsettling times?

\section{Part I: planning theory: a project of unsettlement in need of unsettling?}

Planning is, almost by definition, driven by a desire for "settlement": a way of inscribing the legal and regulatory order that facilitates the socio-spatial and material inhabiting of a particular lot, neighborhood, city, or region. "Settling" and "settlement" also apply to the more political and procedural dimensions of planning practice. As STS scholar Langdon Winner (1986) suggests, politics can be understood as a "way of settling an issue in the affairs of a community" (p. 22, emphasis added). ${ }^{2}$ In this regard, the same might also be said of planning, understood as an extension of politics: a set of practices designed to secure a settlement about the long-term development of a community that is binding across time and space. These physical and political processes of settlement and settling are not only deeply interconnected, but also fix our ways of collectively inhabiting and making decisions to particular spatial, political, and cultural orders.

Words like "unsettle," "unsettlement," and "unsettling" are, therefore, evoked by scholars to disrupt, and to call to account the regressive ways in which structures, processes, and relations impede equity, justice, and ecological sustainability. The call to "unsettle" (e.g. this paper aims to unsettle ...) often signals an impulse to challenge the dominant forces that shape settlements, mobilities, knowledges, relations, and experiences. More generally, we might see "unsettling" as a characteristic move of critical, post-structuralist analysis that seeks to expose the contingency underpinning all social arrangements. Foucault's (1991) genealogical approach to recasting the history of the present, for example, is founded on a desire to unsettle taken-for-granted categories of knowledge, rendering visible the power relations they conceal so that they can be opened to challenge.

Disciplinary development too occurs partly through the unsettlement of prevailing theory. Across the critical social and political sciences, the richness of any given subdiscipline can arguably be measured by the efforts of scholars to unsettle the various ways we interpret and come to know the world. This is not to suggest a teleological process of disciplinary development, or even a series of paradigm shifts within which dominant modes of thought come to be progressively displaced (Sandercock, 1998b). Rather, it is to value a constant process of critical questioning, reframing, and restless searching.

Despite being a relatively recent endeavor within a young and still disputed disciplinary field (Beard and Basolo, 2009), planning theory has itself developed through 
successive efforts at unsettlement. For example, agonistic planning theory emerged through critique of prevailing conceptions of communicative rationality (Hillier, 2003; Ploger, 2004), while the ascendency of agonism has itself given rise to research exploring the role of post-politics in planning theory (Allmendinger and Haughton, 2012; Metzger et al., 2015). Processes of unsettlement like these often occur in magpie fashion by borrowing insights from related fields - sociology, political theory, and urban geography to name a few - and bringing them into conversation with specific challenges of planning practice. Such productive borrowings are one way of unsettling established approaches to reveal their normative and explanatory limits. These borrowings also suggest a reliance on ideas from outside the discipline rather than the development of a distinctive theoretical tradition. Indeed, this has led some scholars to question if planning theory can even be considered a viable proposition (Huxley and Yiftachel, 2000). At least one experienced voice has also recently expressed doubts about the purpose of a field that seems to be marked by an ever-increasing diversity of approaches and concerns (Faludi, 2017: 102). In response, it seems important that we continue to debate the nature and value of contemporary planning theories, a process that requires a commitment to critical engagement and unsettling of established ideas and practices (Friedmann, 2003; Thomas, 2004).

Space constraints preclude a full review of prevailing approaches to planning theory or a critical engagement with what may need unsettling within them. Our intention here is not to be iconoclastic and we do not wish to risk proceeding through sweeping generalizations. Recently published companions (Healey and Hillier, 2010), collected and reflective essays (Haselsberger, 2017; Healey and Hillier, 2008), and handbooks (Gunder et al., 2018) illustrate the diversity of approaches and orientations within contemporary planning theory and perhaps also point toward a desire to take stock, both of roads taken and missed. Within such volumes, it is possible to trace foundational and enduring concerns to sensitize planning scholarship and practice to the lived realities of spatial injustices, the historical and contemporary role planning has played in their perpetuation, and the value of different ways of struggling against them. Such concerns should be nurtured, valued, and mined for their continuing capacity to unsettle mainstream practices that carry on regardless.

Many of us continue to frame our work through the terms of these established theories of planning, and they offer powerful tools for thinking and acting in the world. But it is also important to question the adequacy of their response to contemporary challenges and to interrogate the extent to which their rationalities may continue to rely on any number of settled understandings about planning that pre-suppose a relational order in which, for example, people are equal, things are inert, space is available, knowing is conclusive, and power is tractable. We admire and perhaps aspire to these presumptive conditions, but we cannot assume their presence without obscuring the uneven power relations characteristic of colonialism, sexism, racism, neoliberalism, globalization, and environmental degradation.

In the sections that follow, four short commentaries by Juan, Susmita and Megan, Juliana, and Andrew respond to different facets of the challenge of unsettling planning theory by variously considering (1) whether and how existing planning theories are adequate to deal with key conflicts or challenges, (2) what theoretical problems remain and 
are in need of possible unsettling, and (3) what theoretical tools or borrowings might enable such an unsettling and assist with the further development of planning theory. All the contributions are personal responses that are representative of the connections the authors drew between themes raised at the workshop and their own areas of scholarship. We have intentionally formatted these as a series of "essays within an essay," allowing the authors to write in their own voices. We therefore include their names and institutional affiliations at the beginning of their respective contributions to allow readers to discern who's who. Each commentary ends with a collective response (in italicized text) from Andy, Anne, Crystal, and Janice that returns to the themes and concerns laid out above, pulling out threads that link these commentaries together.

\section{Part 2: commentaries and responses}

\section{Fail again, fail worse: the planning virtues of unsettled theory}

Juan J Rivero. The introduction to this essay evokes ongoing struggles to assimilate and reconcile planning theory and practice with theories and realities of structured inequality. Not coincidentally, it also recalls a movie night from a few years back. The event was a screening of My Brooklyn, a documentary that tells the story of the gentrification of Downtown Brooklyn through one of the filmmaker's efforts to make sense of her own recent arrival in this transitional neighborhood. It depicts the displacement of long-standing independent businesses as a result of a planning effort to upzone the district and bring it closer in line with the affluent neighborhoods that abut it. After the screening, a panel consisting of one of the filmmakers, a planner activist-scholar, and a member of a local advocacy group commented on the developments covered by the documentary and fielded questions from the audience.

My Brooklyn, like good films of its kind, has a way of getting under the viewers' skin, and such was the effect on the event's over-capacity crowd, which included veterans from the protests against the rezoning. One of them memorably asked the planning scholar what she and fellow activists could have done differently. The professor called for more community involvement. The activist, visibly frustrated, pointed to the substantial community efforts that had just yielded such little fruit.

The post-film panel followed a well-settled structure of academic presentations on gentrification - a tale of marginalization, featuring a familiar cast, and culminating in an expected and unsatisfying recommendation. Predictability does not necessarily detract from scholarly merit. Like the blues, some stories bear repeating and make a contribution in the telling, even when you know full well how they're going to end (Baby gonna leave; gonna feel like cryin'). Unlike the blues, however, planning scholarship must do more than deepen our understanding of loss; it must guide planning action. It must respond to the question posed by the audience member at the My Brooklyn screening, "What can we do now?"- a question that settled planning narratives can never satisfactorily answer, because their settled state depends on glossing over planning practice contingencies that not only complicate but also actively shape the translation from knowledge to action.

Postmodern theorists, in repudiating the solidity of essentialist grounding, prefer to unsettle (or problematize or interrogate) than to debunk and thereby presume 
an affirmative step toward a definitive truth. They eschew the goal and possibility of definitive theoretical advancement in favor of progress premised on a provisional reframing of theoretical precedent. Progress, however, in terms of what? In the quotation above, Friedmann resolves this post-foundationalist conundrum by differentiating between a better understanding borne out of dispassionate observation (a conceit central to not only journalism but also the social sciences) and a better understanding organized around a program of action directed toward a desired end. In this formulation, planning theory stands out for its primary focus on purposive intervention and agency, however fluid the distinction between theory and action may be.

Whether construed as a technocrat, negotiator, advocate, or mediator, the planner acts on the basis of both theory in planning and theory of planning. In other words, planning action requires knowledge of what is being acted upon and of how to act upon it - a distinction blurred by planners' embeddedness in their context of operation. Returning to the case of My Brooklyn, our understanding of the multi-scalar, over-determined, class process that is gentrification becomes actionable to the extent that it accounts for the variable goals and positionalities of the planner and other participants in the planning process. Conversely, the applicability of theories of planning hinges on their capacity to grapple with complexity as it arises in the field of practice. Because of this mutual dependence, the rightness of theories about the object of planning must be certified through action rather than empirical verification or a hopeful, postmodern aspiration that knowledge (being power) will somehow lead to better results.

The introduction identifies several dominant theoretical trends: communicative, agonistic, and radical. Although this categorization sets aside important variations within these traditions, it does bring into relief their defining orientation as well as the difficulties that they present for the planning practitioner. Communicative planning challenges the universalistic assumptions that undergird technical expertise, privileging instead authority grounded in collaborative deliberation and casting the planner as a mediating agent. Agonistic planning questions the counter-hegemonic potential of collaborative deliberation, hitching its hopes of political transformation instead on adversarial engagement. Radical planning reacts to the profession's conservative rationalities and seeks progressive change through not just conflictual means but also audacious and creative planning intervention (Sandercock, 2004).

The elaboration and differentiation of these positions on a theoretical plane have long relied on categorical assertions that elide ambiguities at the heart of planning practice. We do not have to embrace the excesses of high modernist planning to recognize that technical expertise plays an indispensable role in the process of collaborative deliberation and certainly in the management of settled matters no longer contested in the deliberative arena. The logical impossibility of absolute inter-subjective understanding raised by sympathizers of agonistic theory may serve as fodder against communicative planning in post-structuralist debate (Purcell, 2009), but it has little bearing on pragmatic efforts to improve understanding in the service of collaborative action. Capitalist development logics may well prevail in mainstream planning, as radical planning theorists maintain, but you would have to subscribe to a totalizing conception of capitalism and willfully ignore the greater equity of alternative "capitalist" arrangements to foreclose the possibility of meaningful progressive change within existing structural constraints. 
In these and similar examples, theorizing (as an intellectual and institutional practice) valorizes qualities - coherence, distinctiveness, elegance - that, rather than enhance, may impair its applicability. This leads planning theory to make not only unwarranted assumptions concerning the extent of people's equality or of power's tractability - but also an unwarranted assumption about the possibility of sorting out such inequality and intractability at the level of theoretical abstraction. To meet the requirements of planners as agents of action situated within a fluid political landscape, theorists would do well to balance efforts to settle the merits of theoretical propositions with greater emphasis on the limitations of those propositions in their application. The recognition that compelling theorizing does not necessarily entail theoretical innovation demands more than a mere reassertion of epistemological humility. It calls for both a reconsideration of the scope of planning within conditions of structured inequality and a rethinking of the practitioner's travails (Krumholz, 1982; Laws and Forester, 2015; Throgmorton, 2000) as emplaced within that field of action (Fainstein and Fainstein, 1979; Foglesong, 1986).

The "failure" of planning theory lies not in its inability to forestall spatial injustice but in its tendency to explain it through a set repertoire of narratives, as if these "classics" were universally applicable and actionable. A more satisfactory answer to the $M y$ Brooklyn question - what do we do now? - may very well have still turned to standard accounts of gentrification and prescriptions of community involvement, but it would have done so to also shed light on how this assessment failed to account for challenges posed by the contingencies of this particular case. Through such an approach, planning theory might guide action not through mastery of ingenious abstractions but through an ongoing reflection on failure and perpetual unsettlement.

Unsettling what it means to produce "actionable" knowledge lies at the center of Juan's contribution. Calling for purposive intervention, Juan seeks to foreground the "what" of knowledge production. That is, what is it we wish to know? What are we producing knowledge for? In light of the challenges presented at the start of this essay, Juan is perhaps asking us to evoke a pragmatism through which substantive planning challenges can become better "known" and new strands of theorizing about the disparate actions and ends desired might become possible. Importantly, the process of knowledge production is a situated practice that draws inspiration from seeking new ways of knowing general problems within specific contexts, such as gentrification in Brooklyn. In other cases, the problems we identify are perhaps more fully structural, historical, and hegemonic, such as private property rights in the case below, with important implications for how we might unsettle processes of knowledge production.

\section{Questioning property in planning}

Susmita Rishi and Megan Horst. As noted in the opening paragraphs, "unsettling" often signals an impulse to challenge the dominant forces that shape neighborhoods, cities, and urban regions. In this response, we suggest that one dominant force needing unsettling is Property and particularly Private Property regimes. We begin this piece with a brief discussion of how planning practice and theory has failed to problematize property thoroughly. We then point out two key avenues that planning theory can draw on to deepen its attention to property (without falling into the totalizing conception of capitalism that Juan warns against): alternative epistemologies and ontologies, and contemporary social movements. 
We choose to focus on property because it is fundamental to planning, and because property is at the heart of many structurally rooted inequalities as well as movements for greater justice. As such, property merits a critical and thorough examination from planners. However, planning's current understanding of property is limited, in that it is dominated by the liberal-economistic model of property (Blomley, 2008). This model involves a binary conceptualization of public (state-owned and controlled land) and private property. When we fail to challenge this narrow binary, we ignore alternative options and narrow our scope for intervention (Porter, 2010). For example, planners typically deal with informal settlements by restoring "order" to the city often by bringing them into the fold of formal private land markets. However, subsuming these settlements into the formal economy opens them to the forces of the market including speculation (Mukhija, 2003). Gentrification of these spaces further displaces the original residents, who then move to other settlements only to become squatters again (Samper, 2011). This repeated pattern begs a new approach to property.

Another limitation is that planning interventions have focused primarily on asking where certain uses go. Kruckeberg (1995 in Porter, 2011) suggests we instead ask "to whom do things belong?" This line of questioning begins to unsettle the assumed clarity of property rights and other structures including settler colonialism, racism, sexism, capitalism, and neoliberalism that are at the base of all unequal property relations. By examining the process of settler colonialism, we acknowledge that settlers have claimed Indigenous land as theirs to own and profit from, and that the disruption by settlers to Indigenous relationships to land continues today (Tuck and Yang, 2012). We confront how structural racism limits people of color from owning land in the United States. We also unpack how under neoliberal capitalism, poorer city residents face displacement by more economically advantaged users. Finally, by asking who has the right to land, we also push back against the idea that economic exchange value supersedes use value and that ownership rights supersede all others.

Historically, planning theories have not centered on challenging the liberal-economist model of private property or on understanding how different understandings of property open up possibilities for more just planning. Instead, the main theories of and in planning (e.g. rational comprehensive, advocacy, communicative) have been procedurally focused, with less attention to specific areas of action. Yet some key planning theories do lend support to a focus on property. Advocacy and equity planning, for example, ask planners to attend to the interests of the poor and other historically marginalized groups, a goal that can only be pursued through a critical focus on property. Radical planning challenges market-led planning, including the dominance of private property. This has included some attention to questions of property. For example, scholarship on gentrification has highlighted the influences of capitalism and racism on displacement of vulnerable communities. Scholarship on commons models, like community land trusts, has been developed in response to problems like the lack of affordable housing. These theories can be built upon to better address property.

Some contemporary planning theorists have questioned the dominance of the private property regime (Porter, 2010), though this focus has not necessarily entered the "canon" of planning theory yet. Fawaz (2017) suggests that a limited focus on property leads planning to replicate "the inequalities inscribed in existing property relations" (p. 379) 
while Porter (2011) seeks to unsettle an "assumed clarity of who has the right to what" (p. 117). By focusing explicitly on property, radical planning theorists can not only unsettle the hegemony of private property but also develop new ways of understanding property and valuing relationships to land beyond private ownership.

In this endeavor, planning scholars can learn from Indigenous scholars who have long critiqued dominant property models and discussed alternative forms of land ownership and management. Porter and Barry (2016), for example, explore the complicity of planning in forwarding settler-colonial conceptions of private property and ownership, proposing ways in which we might move toward more respectful coexistence. Moreton-Robinson (2015) shows how a White understanding of land ownership as private property devalues and erases Indigenous ways of understanding and valuing land. Keenan (2015) meanwhile offers an alternative understanding of property as a relationship of belonging that is neither fixed nor essential but rather temporally and spatially contingent (Piedalue and Rishi, 2017). These works illustrate that centering on alternative epistemological frameworks, whether Indigenous, Black, Latinx, or otherwise, might help planners confront not just other ways of knowing property but also other layers of meaning surrounding the term "unsettling."

Planning theorists can also look to contemporary social movements for alternative epistemologies and ontologies of property. Diverse movements around the world, from the Landless Workers' Movement in Brazil and Bhumi Ucched Pratirodh in India, to Western Cape Anti-Eviction Campaign in South Africa and Slum Dwellers International are claiming rights to land and promoting alternative, non-capitalist modes of property ownership. In the United States, Indigenous communities including the Standing Rock Sioux and the Hope, Zuni, Ute, and Navajo are contesting resource extraction and demanding more Indigenous input over their historical but now federally owned land. Leaders of the national Black Lives Matter policy platform are calling for greater Black access to and control of land. Under the Occupy movement, activists have occupied the farm in Berkley, California, as well as in thousands of other places around the world. People without formal housing are working collectively to stake out safe spaces for unhoused people to rest and sleep, such as Right 2 Dream Too in Portland, Oregon. These diverse movements and their non-binary approaches to property should be of great interest to planning theorists.

Susmita and Megan's piece marks an important departure, calling attention to some of the spatial and material practices of planning that may need to be quite fundamentally unsettled. While their commentary quite intentionally draws our focus away from the previous line of questioning about how planning knowledge is produced and by whom, they speak to the potential importance of conflict and agonism. By focusing on a range of struggles that emerge out of a particular and pernicious binary in planning theory and practice, they implicitly (if not explicitly) suggest that the study of counter-hegemonic social movements can signal new ways of understanding and taking action in our urban and regional environments. Juliana's commentary below picks up on this theme and asks us, as theorists, to reconsider how we position ourselves with respect to the social movements we are studying. 


\section{Unsettling detachment in planning theorizing}

Juliana M Zanotto. For theories to help us move toward social justice by guiding purposive intervention, as Juan puts it, theorists must embrace their responsibility to elevate the voices of vulnerable individuals and communities. This requires not only a commitment to the goal of advancing justice (even when it entails failure and perpetual unsettlement) but also a thoughtful and critical consideration of what methods of knowledge production are better equipped to produce such theories. Existing scholarship, particularly agonistic (McClymont, 2011; Ploger, 2004) and insurgent (Miraftab, 2009) theories, rightfully account for the role of politicization, conflict, social mobilization, and counter-hegemonic practices in planning. But, for the most part, theorizing follows mainstream social science methods that centers the role of a neutral, objective observer. Here, I want to argue that the objectivity and distancing of conventional social science methods limit the development of insights that arise from engagement in the field, where interactions with sites and people reveal the complexities, ugliness, and injustices of oppression. Theorization toward social justice requires theorists to unsettle detachment in planning theory and to be present - body, mind, and heart - in the field.

The need to unsettle detachment in theorizing does not emerge from the conclusion that existing theories are unable to address current challenges. It comes from the realization that what urban planners perceive as current challenges (i.e. police brutality, xenophobia, racism, segregation, inequality, informality) are rather old, historically ingrained, challenges that planning theories and the practices they inform have failed to address. Trumpism, for instance, does not reveal itself as shocking to those who have experienced overt and covert discrimination as part of their lives and collective history.

The social sciences are no better equipped to address systems of oppression today than they were a 100 years ago when W.E.B. Du Bois $(1940,34)$ noted that "one could not be a calm, cool, and detached scientist while Negroes were lynched, murdered, and starved". Du Bois' disbelief in objectivity and neutrality as adequate scientific methods to deal with the violent reality around him continues to be expressed in the academy today, including among planning theorists. The call for new methods of studying planning underscores the "need to reach far beyond the familiar scope of "explanatory social science"" because "conventional social science has had us waiting in the bus station for our plane" (Forester, 2015: 148). This is a realization that scholars who have become "less patient with research done from a safe theoretical and analytical distance" have embraced (Bollens, 2012: 5).

I will borrow from the insights of Brazilian scholars to illustrate the potential of theorizing from experiences of engagement on the ground. As the city of Rio de Janeiro prepared to host a series of mega events, including the 2016 Olympics, residents of a low-income neighborhood situated in a prime location were constantly threatened with orders of removal. Alleging a variety of reasons, including aesthetic damage, pollution of the adjacent lagoon, threats to the security of athletes, obstruction of a planned bus rapid transit route, and incompatibility with plans for the Olympic Park, the municipality issued several removal orders. These orders ignored the fact that the residents had been granted legal rights to the land and that the peaceful and thriving community had invested in infrastructure. As part of their resistance, residents decided to develop an 
alternative plan that reconciled the technical concerns of the city while preserving their right to the land. They sought the collaboration of two public universities whose planning students and faculty assisted in the co-production of a plan to counter the city's official narrative.

The experience of the planning scholars who participated in the co-creation of the plan afforded them a special position from which to theorize. Writing about this experience, they conceptualize planning as conflictual: "fighting to plan and planning to fight" (Vainer et al., 2016). This framework characterizes planning as a weapon in the confrontation between groups. Though the state is heavily armed with official plans and narratives, communities may equally arm themselves with counter narratives and alternative plans.

Conflictual planning, as theorized from real experiences of conflict, is not about mediation. It is about embracing urban conflictuality as (1) the very mechanism that enables creative and counter-hegemonic actions and conceptions to emerge from within subordinate classes, and (2) the process through which collectives are afforded an opportunity to autonomously occupy the public scene (Vainer et al., 2016). Beyond its similarities to insurgent planning, the experience of conflictual planning highlights the production of plans as oriented by the nature and context of the conflict in question. In this way, the methods and contents of plans evolve depending on what weapons are needed to fight each battle (Vainer et al., 2016). Thus, planning becomes a counter-hegemonic practice of resistance against state narratives and proposals.

The scholars offered to the community the services planners often provide to developers and public agencies. On the ground, they were not neutral and detached observers reporting on the development of a conflict and/or theorizing ways to understand the mechanisms involved. They were not interested in objective analysis. They were, instead, fully aware of the politics of their work and their ability as scholars and planners representing both a prestigious academic institution and a legitimate professional field to lift up the voices of the most vulnerable.

Juliana's commentary takes us further by inquiring how, as theorists, we might produce knowledge differently in response to the enduring realities of dispossession, discrimination, and displacement discussed by Megan and Susmita. Echoing Juan, she calls for a praxis that actively engages with the world, chooses sides, and forges solidarities in order to "raise the voices of the vulnerable." Producing planning theory in this way requires a questioning of academic detachment that may be profoundly unsettling of existing knowledges, relations, and identities. Perhaps an ethical response to an unjust world requires that we put more of ourselves on the line, opening up to the creation of new and deeply felt attachments. In our final contribution, Andrew takes these themes about the relational and affective dimensions of knowledge production further. He asks whether, in unsettling times, we might actively embrace a "productive spirit of restlessness," underpinned by a pragmatic and poetic ethos of love, capable not just of engaging with friends but also of struggling with foes.

\section{Remaining unsettled}

Andrew Zitcer. Unsettling times call for unsettling measures. As the Introduction makes clear, planning theory requires a constant interrogation of our habits of inquiry and 
sense-making. This reckoning only increases in urgency as the disconnect between our values and the world around us grows starker. Though we might desire resolution, we should cease our longing for some imagined period of continuity and stability. Rather, we should make permanent our state of unsettlement, since settlement frequently perpetuates injustice. We need only to look to the ongoing violence of settler colonialism, and the initiatives that have arisen to combat it, as described by Susmita and Megan. By unsettling property relations, activists around the world advance spatial justice. As planning theorists and practitioners, Juan reminds us that we are embedded in a dialectical relationship between theorizing in planning and theorizing about planning. Those who value theory must seek to integrate these impulses; we cultivate the capacity for reflection-in-action, rather than the reductive sort of technical mastery that alienates as many as it dazzles.

Ultimately, spatial justice, rendered in a spirit of productive restlessness, depends on theory and methods that may sound strange on our planner's lips. We need to collectively cultivate a vocabulary suited to this moment. Perhaps our incantation can take the following form: pragmatism as the theory, poetry as the method, the ethos is love. (Sometimes these reimaginings are based on very old ideas.) By mouthing these words, let us recover even a temporary firmness beneath our feet.

Why begin with pragmatism? It is an approach that embraces precisely the sort of uncertainty we describe in this provocation. As an anti-foundationalist philosophy, pragmatism rejects dualisms of theory and practice, process and outcomes (Lake, 2016: 1208). Rather than seeking to determine a fundamental reality and hold firm to it, pragmatism searches out what works under a given set of conditions. Recent planning scholarship has brought Deweyan pragmatism back to light (Forester, 2013; Lake, 2016, 2017), imbuing it with a contemporary urgency. As a critical project, pragmatism seeks to perfect democracy through "the moral practice of openness to others in the collective project of hammering out answers to the question of how we should live" (Lake, 2017: 480). Many of the challenges identified in this essay could find the stirrings of a solution in a planning context grounded in moral practice.

A planning context informed by pragmatism must be simultaneously animated by suitable methods of inquiry. Alongside careful rational questioning of our circumstances, we must make room for other ways of knowing and disseminating knowledge. Beginning in the late 1980s, Richard Rorty began to trace a poetic logic through (Western) philosophy and literature. He sought wisdom in these forms of narrative, combining "a desirable openness to new proposals with familiarity with the fates that have overtaken many past proposals" (Rorty, 2016: 61). The method he advocates is not a poetics of Platonic ideals; it is a poetics of process and becoming. Rorty's narrative-infused pragmatism should be placed alongside calls within planning for more focus on dramaturgy (Rannila and Loivaranta, 2015), film (Sandercock and Attili, 2010), and the training of planners to write stories (Baum, 2017). Such imaginative planning methods deliberately unsettle the manner in which knowledge is produced, often opening up spaces for dialogue with citizens who are unmoved by technical rationality and may be stuck in narratives that limit their ability to dream into the future.

Encouraging people to dream requires an ethic of love. Love is a scarce resource in the contemporary public sphere; all the more reason to seek its development. Overcoming detachment, as Juliana makes clear, is fraught with possibilities, including anger, 
sadness, and shock. But we must throw open that door, knowing that any quest for justice is ultimately a product of love. Without love and the trust that undergirds it, planning processes are governed by unequal power relations. Love may be a corrective, but it is also a process, not an ideal state; the work of love is never finished. According to bell hooks (2000), the act of loving the other needs to be undertaken fearlessly and with a critical awareness of love's ethical tensions (Kondo, 2012). There are a number of practical actions we planners can perform to build a trusting relationship in the communities and classrooms where we work. Young's (2000) discussions of greeting, rhetoric, and narrative are helpful guides to stimulate loving praxis. But we must be clear what we mean when we use the word "love." Love comes in many varieties. There is a danger to get caught up in agape, the "Gift-love" that views the other as a hapless soul to be saved, out of the goodness of our hearts (Zitcer and Lake, 2012). Instead, we ought to cultivate philia, a form of political friendship that is based on reciprocal communication, vulnerability, and shared risk.

Hannah Arendt maintains that such public expressions of love should advance the project of freedom, as opposed to love's private, exclusive, and unpolitical manifestations (Chiba, 1995). Liberation lies in an agonistic, public project of reckoning with love's political character. It is easy, after all, to feel love for those with whom we make common cause, or for whom we bear sympathy. But that is not what the moment demands. We must also encounter and struggle with those whose ideas we find unsettling. To find philia among these challenging others may require acknowledgment of the other within ourselves. We can form common cause through hopeful and loving examples, from expressions of cathartic communal dance led throughout Canada by Indigenous activists (Weir, 2017) to interfaith movements to protect Muslims from harassment as they pray. We learn from the Indigenous planning scholars cited at the beginning of the provocation that many struggles in planning ought to be led by communities that have their own ways of knowing, being, and doing. Unsettling from a distance can only get so far; there will be times when activist-planner-scholars must hang back. In these moments, we might find ways to stand in solidarity in support of new manifestations of spatial justice. But while we seek justice and ameliorations of the conditions of crisis, we will not seek closure of our hearts and minds. Our unsettlement, our restlessness will be our strength.

Andrew's evocative call for philia in our planning relations brings us to an aspirational place of tolerance for and patience with ourselves, as we try to understand the practical and theoretical challenges of situated knowledge and planning action. This commitment helps to make sensible (Weick, 1995) the shared process of the workshop and collective essay itself: emergent and not-neat, our conversation has threaded through time and space, seeking to embolden and connect, rather than control and delimit. Concluding, then, poses an especial challenge; our voices are hardly rising in unison, and this seems quite hopeful, intellectually, if not yet harmonious. Juan implies that the context for action should better inform planning inquiry and interpretation; Susmita and Megan foreground a context for action that is itself problematic, asking us to interrogate its pervasiveness, perhaps even as we act within it. Juliana insists that we form attachments to planning contexts that compel, rather than politely invite us to act, and Andrew situates these fundamentally political relations of our work, inquiry, and affiliations in the paradox of a love that is public, patient, pragmatic, and personal. 
It is the personal where we conclude: the ongoing task of learning through, for, and with each other, seeking to act for justice in our planning communities, activist, academic, and otherwise, and beginning with a willingness to unsettle and possibly reorient the bounds and intents of our own self-knowledge.

\section{Part 3: conclusion: planning theorizing as an unsettling exercise in the production of knowledge}

Reflection is the courage to make the truth of our own presuppositions and the realm of our own goals into the things that most deserve to be called into question.

Heidegger (1977: 116).

There is the shared sense running through the contributions above that our embeddedness in the systems of thought and action that shape spatial planning and its theorization may keep us from grasping pressing and consequential realities of the current age. Various fields proclaim that we are moving from one era, to another, as-yet poorly defined and "set in place" through representations of Nature and history as Heidegger (1977) puts it (p. 127) - for instance, out of Modernity, resource abundance, and widespread democratization; into the Anthropocene, planetary urbanization, technological transformation, climate change, and growing class inequality. As we encounter and experience a rapidly changing world, the question of how our own worldviews - our "being in the world" (Low and Sturup, 2017) - influence, or hold us back and keep us from accurately apprehending and acting constructively becomes an essential question for planning theory. Are our knowledge practices reproducing the problems that we study? Inevitably, a multiauthored exploration like this does not and cannot contain a definitive response to such a question, but this essay has argued that the times we are now living through require a shared commitment to keep asking, and trying to answer, such seriously unsettling questions.

Our conclusions are therefore necessarily tentative and by no means a throwing-over of the theory that has guided our planning inquiries and pedagogies — nor could they be perhaps, reliant as we are on the established ways of knowing that organize our faculties of perception, interpretation, and communication (and which have shaped our formation as planning scholars). Rather, this is a call to consider anew the worldview forming academic research and planning practice, making space for a "creative questioning and shaping out of the power of genuine reflection" (Heidegger, 1977: 136). Planning scholarship has long valued the power of critical, reflective practice (Forester, 1999; Schön, 1984); a practice that entails an ongoing commitment to reflect on the phenomenon of knowledge production itself (Yanow and Tsoukas, 2009), foregrounding, considering, and problematizing its presumptions and aims. In other words, a foundational commitment to the continual unsettling of our ways of knowing.

The contributions here point toward the ongoing importance of working to sensitize planning theory to its potential complicity in persistent forms of marginalization and oppression.

However, even as our contributions value the tools of deconstruction developed by critical social science, they also recognize the imperative to go further, to imagine and enact alternatives. Moving toward action by engaging constructively in and against forces of 
exploitation and degradation, however, presents its own daunting challenges that frequently unsettle what we know, how we act and relate to others, and even who we think we are. Unsettlement is not only a condition of the contemporary world or a question of what planning theory is or is not doing for us then; rather, it is also crucial to any examination of our own dispositions toward the practice of theorizing, the habits of inquiry, interpretation, and relational sense-making that emerge from myriad situated encounters where knowledge becomes action. In this regard, our best response to unsettling times may be to continue learning, struggling to know as we act in respectful and loving solidarity with others.

\section{Acknowledgements}

The order of authorship is alphabetical. This was a very deliberate choice that was meant to uphold the collective and supportive spirit of the original workshop. The authors would like to thank all those who attended the workshop and roundtable discussion in Portland which stimulated this essay and Ben Davy for his editorial support and guidance.

\section{Funding}

The author(s) received no direct financial support for the research, authorship, and/or publication of this article. Andy Inch would like to acknowledge the support of the Fundação para a Ciência e a Tecnologia in Portugal (grant number: SFRH/BPD/110582/2015).

\section{Notes}

1. This strategy did, however, result in a gathering of predominantly White scholars in a country plagued by ongoing White supremacy and racial oppression. The four organizers acknowledge and take ownership for the failure to sufficiently unsettle the Whiteness of planning theory, which is arguably a significant symptom of the very problems that we sought to unsettle.

2. With thanks to James McMillan for drawing our attention to this quotation.

\section{References}

Allmendinger P and Haughton G (2012) Post-political spatial planning in England: a crisis of consensus? Transactions of the Institute of British Geographers 37(1): 89-103.

Baum H (2017) To learn to plan, write stories. Planning Theory \& Practice 18(2): 305-309.

Beard V and Basolo V (2009) Moving beyond crisis, crossroads, and the abyss in the disciplinary formation of planning. Journal of Planning Education and Research 29(2): 233-242.

Blomley N (2008) Enclosure, common right and the property of the poor. Social \& Legal Studies 17(3): 311-331.

Bollens S (2012) City and Soul in Divided Societies. New York: Routledge.

Campbell H (2012) Planning to change the world: Between knowledge and action lies synthesis. Journal of Planning Education and Research 32(2): 135-146.

Chiba S (1995) Hannah Arendt on love and the political: Love, friendship, and citizenship. The Review of Politics 57(3): 505-535.

Dikeç M (2017) Urban Rage: The Revolt of the Excluded. New Haven, CT: Yale University Press.

Du Bois WEB (1940) Dusk of Dawn: An Essay toward an Autobiography of a Race Concept. New York: Harcourt Brace Jovanovich.

Fainstein NI and Fainstein SS (1979) New debates in urban planning. International Journal of Urban and Regional Research 3(1-4): 381-403. 
Faludi (2017) Understanding and improving planning processes and planning institutions: A moving target. In: Haselsberger B (ed.) Encounters in Planning Thought: 16 Autobiographical Essays from Key Thinkers in Spatial Planning. Abingdon: Routledge, 88-106.

Fawaz M (2017) Planning and the making of a propertied landscape. Planning Theory \& Practice 18: $365-384$.

Foglesong RE (1986) Planning the Capitalist City: The Colonial Era to the 1920s. Princeton, NJ: Princeton University Press.

Forester J (1999) The Deliberative Practitioner. Cambridge, MA: The MIT Press.

Forester J (2013) On the theory and practice of critical pragmatism: Deliberative practice and creative negotiations. Planning Theory 12(1): 5-22.

Forester J (2015) What kind of research might help us become better planners? Planning Theory \& Practice 16(2): 145-148.

Foucault M (1991) Neitzsche, genealogy, history. In: Rabinow P (ed.) The Foucault Reader. London: Penguin Books, 76-100.

Friedmann J (1987) Planning in the Public Domain. Princeton, NJ: Princeton University Press.

Friedmann J (2003) Why do planning theory? Planning Theory 2(1): 7-10.

Friedmann J (2008) The uses of planning theory: A bibliographic essay. Journal of Planning Education and Research 28(2): 247-257.

Gunder M, Madanipour A, Watson V, et al. (2018) The Routledge Handbook of Planning Theory. Abingdon: Routledge.

Haselsberger B (ed.) (2017) Encounters in Planning Thought: 16 Autobiographical Essays from Key Thinkers in Spatial Planning. Abingdon: Routledge.

Healey P and Hillier J (eds) (2008) Critical Essays in Planning Theory, volumes 1-3. Farnham: Ashgate.

Healey P and Hillier J (eds) (2010) The Ashgate Research Companion to Planning Theory. Farnham: Ashgate.

Heidegger M (1977) The age of the world picture. In: Science and the Quest for Reality. London, UK: Palgrave Macmillan, 70-88.

Hillier J (2003) Agon'izing over consensus: Why Habermasian ideals cannot be 'Real'. Planning Theory 2(1): 37-59.

hooks b (2000) All about Love: New Visions. New York: William Morrow.

Huxley M and Yiftachel O (2000) New paradigm or old myopia? Unsettling the communicative turn in planning theory. Journal of Planning Education and Research 19: 333-342.

Keenan S (2015) Subversive Property: Law and the Production of Spaces of Belonging. Oxon: Routledge.

Kondo MC (2012) An ethic of love for planning. Planning Theory \& Practice 13(4): 603-605.

Krumholz N (1982) A retrospective view of equity planning Cleveland 1969-1979. Journal of the American Planning Association 48(2): 163-174.

Lake RW (2016) Justice as subject and object of planning. International Journal of Urban and Regional Research 40(6): 1206-1221.

Lake RW (2017) On poetry, pragmatism and the urban possibility of creative democracy. Urban Geography 38(4): 479-494.

Laws D and Forester J (2015) Conflict, Improvisation, Governance: Street Level Practices for Urban Democracy. Abingdon: Routledge.

Low N and Sturup S (2017) Being and planning, world formation and authenticity in Heideggerian analysis. Planning Theory 17(3): 313-331.

McClymont K (2011) Revitalising the political: Development control and agonism in planning practice. Planning Theory 10(3): 239-256. 
Matunga H (2017) A revolutionary pedagogy of/for indigenous planning. Planning Theory \& Practice 18(1): 640-644.

Metzger J, Allmendinger P and Oosterlynck S (2015) The contested terrain of European territorial governance. In: Metzger J, Allmendinger P and Oosterlynck S (eds.) Planning Against the Political: Democratic Deficits in European Territorial Governance, Abingdon, Routledge, 1-28.

Miraftab F (2009) Insurgent planning: Situating radical planning in the global south. Planning Theory 8(1): 32-50.

Moreton-Robinson A (2015) The White Possessive: Property, Power, and Indigenous Sovereignty. Minneapolis, MN; London: University of Minnesota Press.

Mukhija V (2003) Squatters as Developers? Slum Redevelopment in Mumbai. Aldershot; Burlington, VT: Ashgate.

Patrick L (2017) Indigenist planning. Planning Theory \& Practice 18(1): 647-649.

Piedalue A and Rishi S (2017) Unsettling the South through postcolonial feminist theory. Feminist Studies 43(3): 548-570.

Pløger J (2004) Strife: Urban planning and agonism. Planning Theory 3(1): 71-92.

Porter L (2010) Unlearning the Colonial Cultures of Planning. Aldershot: Ashgate.

Porter L (2011) Informality, the commons and the paradoxes for planning: Concepts and debates for informality and planning. Planning Theory \& Practice 12(1): 115-153.

Porter L and Barry J (2016) Planning for Coexistence? Recognizing Indigenous Rights through Land-Use Planning in Canada and Australia. Abingdon: Routledge.

Purcell M (2009) Resisting neoliberalization: Communicative planning or counter-hegemonic movements? Planning Theory 8(2): 140-165.

Rannila P and Loivaranta T (2015) Planning as dramaturgy: Agonistic approaches to spatial enactment. International Journal of Urban and Regional Research 39(4): 788-806.

Rorty R (2016) Philosophy as Poetry. Charlottesville, VA: University of Virginia Press.

Samper J (2011) Urban regeneration in a context of violence: The case of the Favela-Bairro in Rio de Janeiro. Informal Settlements Research, 21 June. Available at: http://informalsettlements. blogspot.com/2011/06/urban-regeneration-in-context-of.html

Sandercock L (ed.) (1998a) Making the Invisible: A Multicultural Planning History. Berkeley, CA: University of California Press.

Sandercock L (1998b) Towards Cosmopolis. Chichester: Wiley.

Sandercock L (2004) Towards a planning imagination for the 21 st century. Journal of the American Planning Association 70(2): 133-141.

Sandercock L and Attili G (2010) Multimedia Explorations in Urban Policy and Planning: Beyond the Flatlands. New York: Springer.

Schon D A (1984) The reflective practitioner: How professionals think in action (Vol. 5126). New York, Basic Books.

Streeck W (2016) How Will Capitalism End? London: Verso Books.

Thomas H (2004) What future for British planning theory. Planning Theory 3(3): 189-198.

Throgmorton JA (2000) On the virtues of skillful meandering. Journal of the American Planning Association 66(4): 367-383.

Tuck E and Yang KW (2012.) Decolonization is not a metaphor. Decolonization: Indigeneity, Education \& Society 1(1): 1-40.

Vainer C, Bienenstein R, Tanaka G, Oliveira FL, Lobino C, Sanchez F and Bienenstein G (2016) O plano popular da Vila Autodromo: uma experiência de planejamento conflitual. In: Oliveira FL, Sanchez F, Tanaka G and Monteiro P (eds.) Planejamento e Conflitos Urbanos: Experiências de Luta. Rio de Janeiro: Letra Capital, 27-64.

Watson V (2003) Conflicting rationalities: implications for planning theory and ethics. Planning Theory \& Practice 4(4): 395-407. 
Weick KE (1995) Sensemaking in Organizations. Thousand Oaks, CA: SAGE.

Weir A (2017) Collective love as public freedom: Dancing resistance. Ehrenreich, Arendt, Kristeva, and idle no more. Hypatia 32(1): 19-34.

Winner L (1986) Do artifacts have politics? In: Winner L (ed.) The Whale and the Reactor: A Search for Limits in an Age of High Technology. Chicago, IL: University of Chicago Press, 19-39.

Yanow D and Tsoukas H (2009) What is reflection-in-action? A phenomenological account. Journal Of Management Studies 46(8): 1339-1364.

Young IM (2000) Inclusion and Democracy. Oxford; New York: Oxford University Press.

Zitcer A and Lake RW (2012) Love as a planning method. Planning Theory \& Practice 13(4): 606-609.

\section{Author biographies}

Janice Barry is an assistant professor in the Department of City Planning at the University of Manitoba, with research interests in participatory processes, discourse analysis, and communityengaged teaching and research. Her empirical work interrogates the links between settler colonialism and land use planning in both urban and rural areas.

Megan Horst is an assistant professor in the Toulan School of Urban Studies and Planning at Portland State University. Her research interests include planning theory, land use planning, food systems planning, and social justice.

Andy Inch is a post-doctoral researcher at the Instituto de Ciências Sociais, Universidade de Lisboa, Portugal. From May 2018 he will take up a post as a Senior Lecturer in the Department of Urban Studies and Planning at the University of Sheffield, UK. His research curently focuses on the politics of planning, how planning engages with the future and relations between citizens and the state.

Crystal Legacy is a Senior Lecturer in Urban Planning at the University of Melbourne, Australia. Crystal conducts research in a wide range of areas, including transport, housing, and strategic planning. Crystal's current research examines the politics of urban transportation planning with a specific focus on the role of the citizen in contested transport processes in Australian and Canadian cities. Crystal has widely published in a range of journals and outlets such as The Conversation. She is the co-editor of Building Inclusive Cities: Women's safety and the right to the city (Routledge, 2013) and of Instruments of Planning: Tensions and Challenge for more Equitable and Sustainable Cities (Routledge, 2016).

Susmita Rishi is a candidate in the Interdisciplinary Ph.D. program in Urban Design and Planning at the University of Washington, Seattle. Her research interests include politics of governance, representation, and informal urbanism in the urban Global South. Her dissertation research explores subjective understandings of value and property, in the self-built and appropriated spaces of informal settlements.

Juan Rivero is a term assistant professor in the urban studies program of Barnard College. His research deals with the cultural dimension of urban redevelopment, examining the values that people ascribe to places and how those relate to prevailing planning practice.

Anne Taufen is an associate professor in the Urban Studies program at the University of Washington Tacoma, where she chairs the graduate program in Community Planning. Her research focuses on policy and planning for sustainable urban development, with a focus on narrative constructions of environmental justice, and public access to urban waterways. 
Juliana M Zanotto is a researcher at the School of Social Ecology, University of California, Irvine. Her research focuses on the practices of urban planners and designers to understand the relationship between social processes and the production of spaces.

Andrew Zitcer is an assistant professor at Drexel University's Westphal College of Media, Arts \& Design in Philadelphia, PA, where he directs the Urban Strategy graduate program. His research interests include cooperative social and economic practices as well as the role of the arts in community revitalization. 